\title{
Diagnosis and remediation of physics students' difficulty through the outdoor student remediation teaching (OSRT)
}

\author{
Muslimin $^{1 *}$, Janli Novrenli Makitulung ${ }^{2}$, I Komang Werdhiana ${ }^{3}$, Nurlaila ${ }^{4}$, Agustina ${ }^{5}$ \\ 1, 2, 3, 5 Physics Education, Universitas Tadulako, Central Sulawesi, Indonesia \\ ${ }^{4}$ MTs Negeri 1 Donggala, Central Sulawesi, Indonesia \\ *Corresponding Address: fisikamuslim@gmail.com
}

\begin{abstract}
Article Info
Article history:

Received: February $24^{\text {th }}, 2020$

Accepted: October $14^{\text {th }}, 2020$

Published: October $30^{\text {th }}, 2020$

\section{Keywords:}

Diagnosis;

Learning difficulties;

Remediation;

OSRT treatment.

ABSTRACT

The study's purpose was to describe students' learning difficulties in physics, the causes of students' learning difficulties in physics, and the remediation to solve students' difficulties. This research was exploratory research with qualitative and quantitative approaches. The populations of this study were eleventh-grade students of SMAN 6 Palu. The respondents were chosen based on the lowest posttest results. The research instruments were OSRT treatment, pretest, posttest, and diagnostic test. The data were analyzed by comparing the pretest results, the posttest, and the gain score to determine the improvement after the remediation. Respondent A obtained 0.71 within the high category, respondent B obtained 0.69 within the high category, respondent $\mathrm{C}$ obtained 0.85 within the high category, respondent $\mathrm{D}$ obtained 0.84 within the high category, and respondent $\mathrm{E}$ obtained 0.46 within the moderate category. It can be concluded that internal and external factors caused difficulties. The internal factors were students' weak basic knowledge and weak material prerequisites, while the external factors were the teacher's learning methods that did not attract students' attention. The OSRT can overcome the difficulty in understanding Newton's law's concept to improve their ability to understand physics concepts.
\end{abstract}

(C) 2020 Physics Education Department, UIN Raden Intan Lampung, Indonesia.

\section{INTRODUCTION}

Various learning models and strategies have been implemented to improve the abilities of $21^{\text {st }}$-century students (Redhana, 2019). Students need to face global competition (Afandi et al., 2016; Siahaan et al., 2020). Therefore, students are required to develop their knowledge (Mulhayatiah et al., 2019). However, difficulties are often found in developing the students' knowledge (Hafid et al., 2016). Diagnosis is an alternative to identifying students (Makmun \& Syamsuddin, 2014; Sheftyawan et al., 2018). Remediation can be performed after obtaining the diagnosis results (Efriani et al., 2019; Soewarno et al., 2016). After the teacher can identify students' learning difficulties, the teacher should find the factors that cause the learning difficulties and remedy the misunderstandings (Taufiq, 2012).

Identification of learning difficulties is an important thing to do in the physics learning process (Chen \& Hsiu, 2011). Identification of learning difficulties can be made before, during, and after the learning process, and it needs to be followed up with efforts to keep students from misconceptions (Silung et al., 2017).

Students' learning difficulties must be overcome immediately because it will affect students' understanding of the next subject of physics (Haqiqi, 2018). Remediation efforts in the learning process need to be done 
because it can increase the quantity of understanding and reduce students' misconceptions on the material (Putra et al., 2016).

Increasing student knowledge, thinking, analysis, and thinking ability is needed to correct students' conceptual errors (Wartono et al., 2019). The thinking ability and a high level of analysis can solve problems systematically, logically, and reasonably (Masyuni \& Asyhari, 2019). Therefore, teachers must have sufficient ability or knowledge to overcome students' learning difficulties (Munirah, 2018; Perdana et al., 2019). In the learning process, students often experience difficulties and sometimes misconceptions. To overcome the difficulties, teachers must have the ability to choose the right method (Maulana, 2012; Tarmizi et al., 2017). Checkley (2010) states that teachers must increase students' conceptual understanding and reduce their misconceptions in the learning process.

Research conducted by Lavonen et al., (2005) on students who took science lessons consisting of physics, chemistry, and biology revealed that students who liked chemistry and biology were more than students who liked physics. It is based on the perception that physics material is challenging to understand. A learning process that can overcome these problems is needed to reduce the concept of understanding difficulties. Diagnosis in physics learning must be made to reduce learning difficulties (Alang, 2015; Yolanda \& Yaspin, 2017).

Mastery of physics concepts is essential because they are interrelated so that there are no misconceptions when learning new concepts (Abraham, 2019). Therefore, if students have difficulties with one of the materials or subjects, it is very likely that they will experience difficulties when learning the following material (Alamsyah et al., 2018; Ramadhani et al., 2016). Difficulties in physics learning often hinder the students in understanding and connecting the concepts to be studied. Therefore, it is essential to make a diagnosis to determine students' difficulties (Alamsyah et al., 2018).

Research conducted by (Negoro et al., 2018) revealed that learning that prioritizes error analysis in increasing understanding could reduce students' misconceptions. Remediation should be carried out based on the students' needs (Mulia et al., 2020). Furthermore, the diagnosis of student difficulties can be used as guidelines for designing learning (Abraham, 2019). Maisura (2014) states that students who have not reached the level of success are needed remediation. The remediation can be in the form of assistance from a teacher to students.

Diagnosis aims to identify students' learning difficulties and find solutions (Ismail, 2016). If students' learning difficulties are left as they are, the learning objectives will not be adequately achieved (Makmun \& Syamsuddin, 2014). According to Irwansyah et al. (2018), diagnostic assessment is an instrument to determine learning outcomes to identify or diagnose learning outcomes. Therefore, this study used a diagnostic test to determine students' learning difficulties. It is necessary to diagnose and help the students obtain optimal learning outcomes based on the diagnosis results. Therefore, this research aimed to describe the types, the causes, and the method to overcome the difficulties.

\section{METHODS}

This research was exploratory research with qualitative and quantitative approaches. The research design was an adaptation of the operational approach research design presented in Figure 1 (Makmun \& Syamsuddin, 2014). 


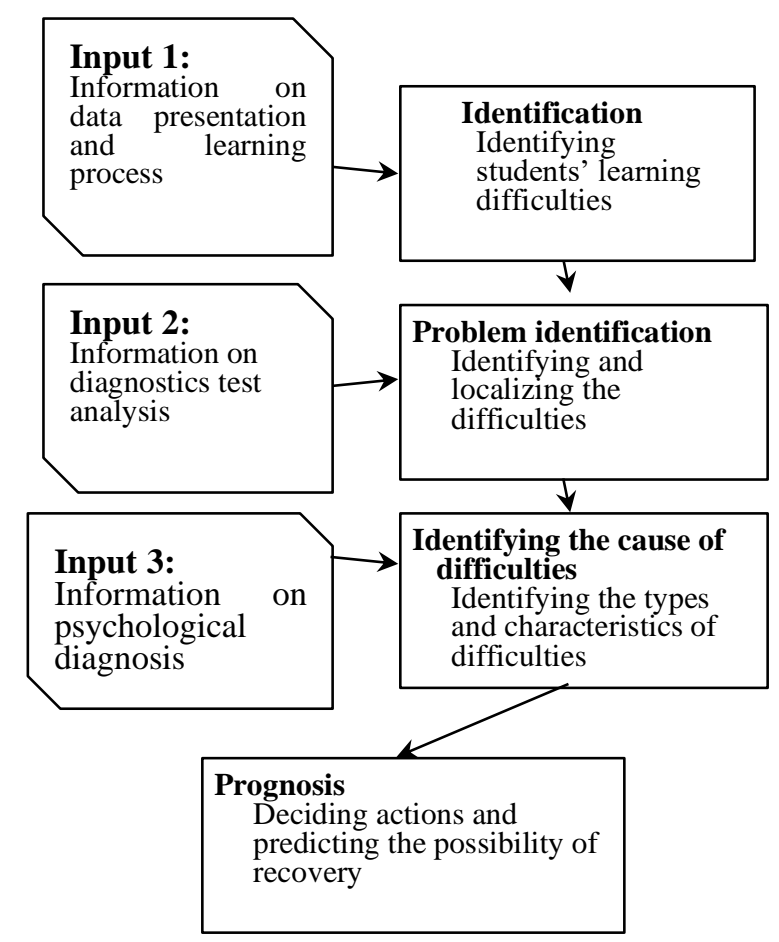

Figure 1. Operational approach pattern

This research population was all students of class X IPA SMAN 6 Palu, which consisted of 7 classes. The experimental class was class X IPA 4 with 32 students. The sampling was based on the random sampling technique. Furthermore, several students were selected as respondents based on the diagnostic test results in the sample class. The selected respondents were those who were in the lowest category.

The instruments used in this study were the OSRT (Outdoor Student Remediation Teaching), pretest, posttest, and diagnostic test. The pretest and posttest instruments were tested using the item validation test (point biserial correlation coefficient), difficulty index, discriminating index, and reliability test. Furthermore, the diagnostic test had been tested through expert validation.

In the data analysis, the gain value was used to determine the improvement after doing remediation using equation (1):

$$
N_{\text {gain }}=\frac{S_{\text {post }}-S_{\text {pre }}}{S_{\text {max }}-S_{\text {pre }}}
$$

$S_{\text {post }}$ is the post-test score, $S_{\text {pre }}$ is the pretest score, and $S_{\max }$ is the maximum score.

\section{RESULTS AND DISCUSSION}

Based on the number of errors on the test's answers, five students with the lowest scores were selected, namely, student 1 , student 4 , student 8 , student 20 , and student 32 . Student 1 was labeled as respondent $\mathrm{A}$, student 4 was labeled as respondent $\mathrm{B}$, student 8 was labeled as respondent $\mathrm{C}$, student 20 was labeled as respondent $\mathrm{D}$, and student 32 was labeled as respondent $\mathrm{E}$. The results of the diagnostic test are displayed in Table 1.

Table 1. Initial test results

\begin{tabular}{lcc}
\hline Respondents & $\begin{array}{c}\text { Number of } \\
\text { Error }\end{array}$ & Score \\
\hline Students 1 & 14 & 30 \\
Students 4 & 13 & 35 \\
Students 8 & 14 & 30 \\
Students 20 & 13 & 35 \\
Students 32 & 15 & 25 \\
\hline
\end{tabular}

The diagnostic test contained essay questions on Newton's first law's sub material and its application, Newton's second law and its application, Newton's third law and its application, types of forces, coefficient of friction, and particle dynamics problems (in lift and pulley). The comparison of students' difficulties based on the pretest results and the post-test test results is presented in Table 2. 
Table 2. The comparison of the pretest and the post-test

\begin{tabular}{|c|c|c|c|c|c|c|c|c|c|c|c|}
\hline \multirow{3}{*}{ Material } & \multirow{3}{*}{ No. } & \multirow{2}{*}{\multicolumn{5}{|c|}{$\begin{array}{c}\begin{array}{c}\text { Location of error } \\
\text { (pretest) }\end{array} \\
\text { Respondents } \\
\end{array}$}} & \multirow{2}{*}{\multicolumn{5}{|c|}{$\begin{array}{c}\begin{array}{c}\text { Location of error } \\
\text { (posttest) }\end{array} \\
\text { Respondents } \\
\end{array}$}} \\
\hline & & & & & & & & & & & \\
\hline & & $\mathbf{A}$ & B & $\mathbf{C}$ & D & $\mathbf{E}$ & $\mathbf{A}$ & B & $\mathbf{C}$ & D & $\mathbf{E}$ \\
\hline \multirow{3}{*}{$\begin{array}{l}\text { Newton's First Law } \\
\text { and its application }\end{array}$} & 1 & - & - & - & - & $\checkmark$ & $\checkmark$ & $\checkmark$ & $\checkmark$ & $\checkmark$ & $\checkmark$ \\
\hline & 2 & $\checkmark$ & $\checkmark$ & $\checkmark$ & $\checkmark$ & $\checkmark$ & $\checkmark$ & $\checkmark$ & $\checkmark$ & $\checkmark$ & $\checkmark$ \\
\hline & 4 & - & - & - & - & $\checkmark$ & $\checkmark$ & $\checkmark$ & $\checkmark$ & $\checkmark$ & $\checkmark$ \\
\hline \multirow{6}{*}{$\begin{array}{l}\text { Newton's second law } \\
\text { and its application }\end{array}$} & 3 & - & - & - & - & $\checkmark$ & $\checkmark$ & $\checkmark$ & $\checkmark$ & $\checkmark$ & $\checkmark$ \\
\hline & 7 & $\checkmark$ & $\checkmark$ & - & - & $\checkmark$ & $\checkmark$ & $\checkmark$ & - & - & - \\
\hline & 12 & $\checkmark$ & $\checkmark$ & - & - & - & $\checkmark$ & $\checkmark$ & $\checkmark$ & $\checkmark$ & - \\
\hline & 14 & - & - & - & - & - & $\checkmark$ & $\checkmark$ & $\checkmark$ & $\checkmark$ & - \\
\hline & 15 & - & - & - & $\checkmark$ & - & $\checkmark$ & $\checkmark$ & $\checkmark$ & $\checkmark$ & $\checkmark$ \\
\hline & 16 & - & - & - & - & $\checkmark$ & $\checkmark$ & $\checkmark$ & $\checkmark$ & $\checkmark$ & $\checkmark$ \\
\hline \multirow{4}{*}{$\begin{array}{l}\text { Newton's third law } \\
\text { and its application }\end{array}$} & 5 & - & $\checkmark$ & - & - & - & $\checkmark$ & $\checkmark$ & $\checkmark$ & $\checkmark$ & $\checkmark$ \\
\hline & 6 & - & - & $\checkmark$ & - & - & - & - & $\checkmark$ & $\checkmark$ & - \\
\hline & 8 & $\checkmark$ & - & - & - & - & $\checkmark$ & - & $\checkmark$ & $\checkmark$ & - \\
\hline & 20 & $\checkmark$ & $\checkmark$ & $\checkmark$ & $\checkmark$ & $\checkmark$ & $\checkmark$ & $\checkmark$ & $\checkmark$ & $\checkmark$ & $\checkmark$ \\
\hline \multirow{3}{*}{ Types of forces } & 9 & $\checkmark$ & $\checkmark$ & $\checkmark$ & $\checkmark$ & - & $\checkmark$ & $\checkmark$ & $\checkmark$ & $\checkmark$ & $\checkmark$ \\
\hline & 10 & - & - & $\checkmark$ & $\checkmark$ & - & $\checkmark$ & $\checkmark$ & $\checkmark$ & $\checkmark$ & $\checkmark$ \\
\hline & 11 & - & - & $\checkmark$ & $\checkmark$ & - & - & $\checkmark$ & $\checkmark$ & $\checkmark$ & $\checkmark$ \\
\hline \multirow{3}{*}{$\begin{array}{l}\text { Particle dynamics } \\
\text { problems }\end{array}$} & 17 & - & - & - & - & - & $\checkmark$ & $\checkmark$ & - & - & - \\
\hline & 18 & - & - & - & $\checkmark$ & - & - & - & $\checkmark$ & $\checkmark$ & - \\
\hline & 19 & - & $\checkmark$ & - & $\checkmark$ & - & $\checkmark$ & $\checkmark$ & $\checkmark$ & $\checkmark$ & - \\
\hline Friction coefficient & 13 & - & - & - & - & - & - & - & $\checkmark$ & $\checkmark$ & $\checkmark$ \\
\hline
\end{tabular}

Description: $\checkmark$ : correct answer and -: wrong answer

Respondents A, B, C, D, and E: The objects of research

Based on the location of the respondent's errors on the pretest, they experienced errors in almost all the subject matter on particle dynamics material. However, after the remediation, the errors had been minimized. It could be seen from the post-test results. When the first diagnostic test was carried out, the respondents forgot or did not even know the concepts and formulas in all the subject matter of particle dynamics. They also forgot how to convert units, quantity and unit, kinematics of straight motion, and vectors.

After conducting the diagnostic test, the researcher conducted remediation in the form of OSRT. The comparison of the pretest and the posttest increased. The increase can be seen in Table 3.

Table 3: Results of Respondents' Gain Score

\begin{tabular}{ccc}
\hline $\begin{array}{c}\text { Responden } \\
\text { ts }\end{array}$ & Gain & Criteria \\
\hline A & 0.71 & High \\
B & 0.69 & High \\
C & 0.85 & High \\
D & 0.84 & High \\
E & 0.46 & Medium \\
\hline
\end{tabular}

The respondents made errors in almost the entire subject matter of the particle dynamics material. To find out more about the difficulties and their causes, a diagnostic test was administered using an instrument in the form of description questions and interviews.

The five respondents did not understand the subject matters on the diagnostic test, such as Newton's first, second, and third law materials, especially the equations. They are even confused by the laws' application in everyday life. All respondents could not describe the forces acting on an inclined plane. They did not even understand Newton's second law, which is the basis for calculating the magnitude of the force acting on the lift and pulley. The statement above can be seen from the sample results of the respondent's works as shown in Figure 2. 


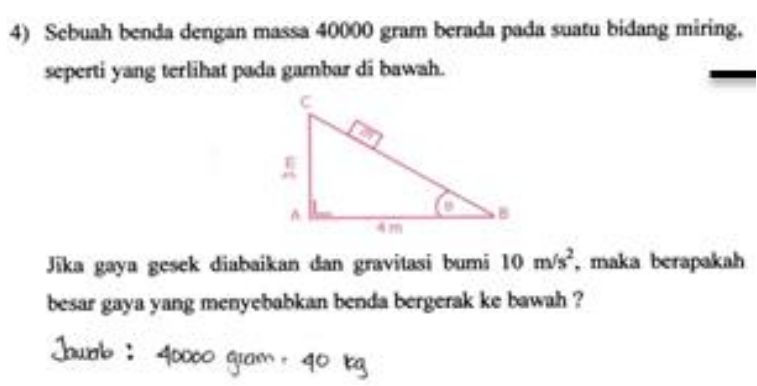

Figure 2.a. Respondent A

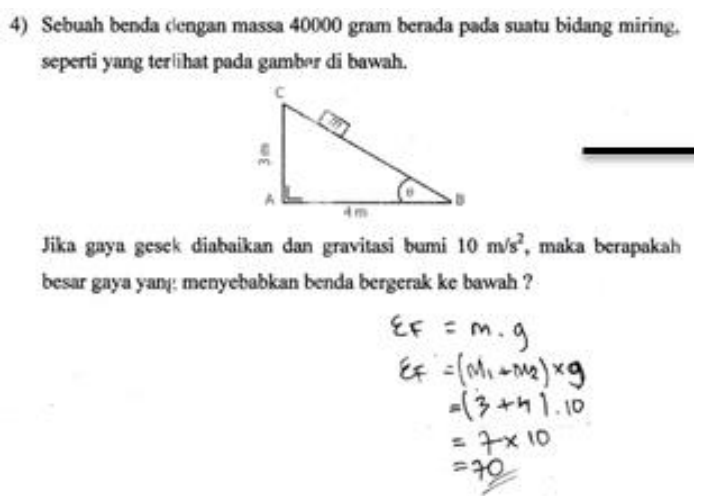

Figure 2.b. Respondent B

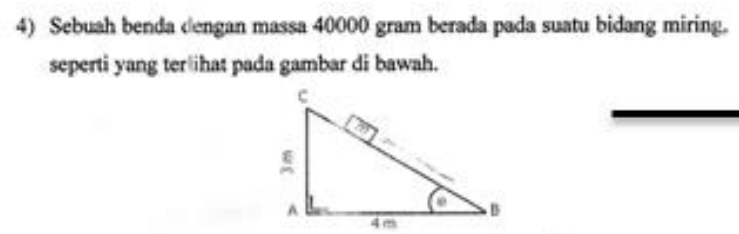

Jika gaya gesek diabaikan dan gravitasi bumi $10 \mathrm{~m} / \mathrm{s}^{2}$, maka berapakah besar gaya yang: menyebabkan benda bergerak ke bawah ?

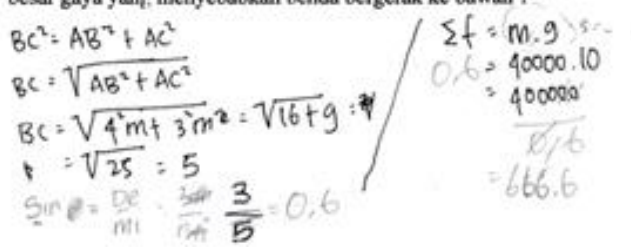

Figure 2.c. Respondent D

Respondents $\mathrm{C}$ and $\mathrm{E}$ did not do the questions.

The respondents who caused the errors did not study beforehand and did not understand the concept of Newton's laws when studying them in the class. The five subjects collected their work quickly even though many things had not been done. They did not know and forgot the formula. The results showed that the respondents' basic knowledge about quantities and units, how to convert units, project the $\mathrm{x}$ and $\mathrm{y}$ (Cartesian) axes, and the Pythagorean formula were categorized as weak. The students had not mastered the basic knowledge, causing difficulties in calculating the force on an inclined plane, on the lift, on the pulley, and so on.

Two main factors cause the five respondents to experience learning difficulties based on the diagnostic interview results. The excerpts of the interview with the respondents are as follows:

$\mathrm{R}$ : How do you study at home?

Rs: Reading books or doing homework.

$\mathrm{R}$ : Are there any difficulties or obstacles while studying at home?

Rs: It is difficult to understand the concept and some equations.

R: Do you often do your homework at home?

Rs: Yes, if I know how to.

R: How does your teacher teach you at school, especially the physics teacher?

Rs: He explains the derivation of the formula, but he does not explain the meaning.

R: Do you like the teacher's teaching method?

Rs: Yes, although he teaches too quickly

$\mathrm{R}$ : How is the learning atmosphere in the class?

Rs: It is fun, but it is hard to understand.

$\mathrm{R}$ : What are the difficulties or obstacles in the classroom?

S: Ability to understand concepts, especially to describe the vectors of forces acting on objects.

Information:

Researcher (R), Respondent (Rs)

Based on the results of the interviews, the respondents found it challenging to understand the concepts because of the teacher's method of conveying the learning material. The identified causes of the respondents' learning difficulties are (1) respondents' inaccurate attitudes and habits indicated by the respondents' statement that they rarely study. They will study only when they are going to take a test or if there is homework; (2) The respondents had low necessary skills based on the physics teacher's statements and the diagnostic interview results; (3) Unfavorable learning situation at school and home (unsupportive families at home and unsupportive learning environment at school); (4) Low motivation to learn; (5) The lack of supporting tools for learning physics provided by the school;

(6) There were no attention-grabbing physics learning methods. 
The research results conducted by Ma'rifah (2017) show that material is challenging to understand due to internal factors, such as physical conditions, learning motivation, learning methods, and social relationships. Apart from internal factors, there are also external factors, namely learning methods, learning resources and materials, and learning hours.

The remediation process had been carried out through OSRT treatments. The treatments were carried out only for students who had difficulties in understanding concepts. Students assisted the treatments with a high level of understanding to guide their peers. After the treatments had been carried out, a posttest was administered ( see Table 3). The results showed that all respondents obtained high gains, except for respondent $\mathrm{E}$. These results can overcome the learning difficulties in several parts of the particle dynamics material based on the posttest score. The results are in line with the research results of Munene et al. (2017). Based on the findings, the majority of respondents strongly agreed that remediation programs improve their performances. However, the remediation often conflicts with other activities, so that it was difficult for students to concentrate during the lessons while other students were playing. It is recommended to formulate a policy on remediation teaching to align it with other school activities. Likewise, the research results (Kumari \& Bhattacharya, 2016), based on multilevel regression analysis, show that the remediation treatment can reduce concept understanding errors.

The gain score showed an increase after remediation. This can be seen from the five respondents' gain score; respondent A obtained 0.71 , respondent B obtained 0.69, respondent $\mathrm{C}$ obtained 0.85 , and respondent $\mathrm{D}$ obtained 0.84 . The four respondents were in the high category. Meanwhile, respondent E obtained 0.46, which was in the moderate category. Hafid et al., (2016) States that remediation teaching in the inquiry model effectively improves students learning outcomes with an average score of higher than 75 and a proportion of mastery of higher than $75 \%$. (Stevenson et al., 2002) state that learning based on the analysis of learning difficulties will encourage students to form and develop self-concepts so that their understanding of concepts and ideas can be stronger (Febri et al., 2020). Other research shows that students' internal factors, motivation, emotions, and control can affect their learning outcomes (Yulika, 2019). The diagnostics of students' internal factors and remediation can improve their abilities. (Kheong \& Fong, 1982) state that learning outcomes can be improved if the teacher first makes a proper diagnosis of students' learning difficulties.

There was an increase in the five respondents' results on the post-test after remediation because the approaches, methods, and models of remediation were different from those usually used by teachers. Researchers used the outdoor study approach and outside school hours model. The approach and model were different because the teachers only used conventional methods of question and answer, which seems boring for the five respondents.

\section{CONCLUSION AND SUGGESTION Conclusion}

Based on the diagnosis and remediation results, it can be concluded that the respondent had difficulty solving the problem of the force diagram projection, calculating the coefficient of friction, and the problem of the working force. Internal and external factors influenced the factors causing the difficulties experienced by the five respondents. The internal factors were the weak basic knowledge and prerequisite materials, while the external factor was the teacher's learning methods. The OSRT can improve students' ability to understand physics concepts.

\section{Suggestion}

Based on the research, the researchers suggest the teacher pay attention to the 
students' difficulties in understanding the concept, especially in the equation derivation explanation activity. The teacher should explain the physical meaning of the equations. Furthermore, for the Outdoor Student Remediation Teaching, the teaching should be assisted by students who understand the concept so that the remediation does not seem dull.

\section{AUTHOR CONTRIBUTIONS}

$\mathrm{MM}, \mathrm{JN}$ and IK developed and prepared research instruments. NN dan AA collected and analyzed data. JN, NN and AA wrote the result and discussion. MM prepared literature related to research. IK prepared research design.

\section{REFERENCES}

Abraham, B. (2019). Effective strategies in remedial instruction. Journal for Research Scholars and Professionals of English Language Teaching, 15(3).

Afandi, Junanto, T., \& Afriani, R. (2016). Implementasi digital-age literacy dalam pendidikan abad 21 di Indonesia. Seminar Nasional Pendidikan Sains, 113-120.

Alamsyah, Mansyur, J., \& Kade, A. (2018). Analisis kesulitan siswa dalam memecahkan soal fisika SMP pada materi usaha dan energi. JPFT (Jurnal Pendidikan Fisika Tadulako Online), 6(1), 40-43. https://doi.org/10.22487/j25805924.2 018.v6.i1.10017

Alang, S. (2015). Urgensi diagnosis dalam mengatasi kesulitan belajar. Al-Irsyad Al-Nafs: Jurnal Bimbingan Dan Penyuluhan Islam, 2(1), 1-14. https://doi.org/10.24252/Aian.V2n1a 1

Checkley. D. (2010). High school students' perceptions of physics high school students' perceptions of physics. A Thesis Submitted to the School of Graduate Studies of the University of Lethbridge.

Chen, L., \& Hsiu. (2011). Enhancement of student learning performance using personalized diagnosis and remedial learning system. Computers and Education, 56(1), 289-299.

Efriani, N., Zulyusri, Rahmi, Y. L., \& Sumarmin, R. (2019). Identifikasi miskonsepsi peserta didik kelas VII SMP Negeri 1 Sutera pada topik fotosintesis menggunakan tes diagnostik Two Tier. Bioeducation Journal, 1(2), 29-36.

Febri, A., Saji, Sarwanto, \& Dewanto, H. (2020). Guided inquiry lab : Its effect to improve student's critical thinking on mechanics. Jurnal Ilmiah Pendidikan Fisika Al-BiRuNi, 9(1), 87-97. https://doi.org/10.24042/jipfalbiruni. v9i1.4630

Hafid, H., Kartono, \& Suhito. (2016). Remedial teaching untuk mengatasi kesulitan belajar siswa pada kemampuan pemecahan masalah matematika berdasarkan prosedur Newman. Unnes Journal of Mathematics Education, 5(3), 257265.

Haqiqi, A. K. (2018). Analisis faktor penyebab kesulitan belajar IPA siswa SMP Kota Semarang. EduSains: Jurnal Pendidikan Sains \& Matematika, 6(1), 37-43.

Irwansyah, Sukarmin, \& Harjana. (2018). Development of three-tier diagnostics instruments on students misconception test in fluid concept. Jurnal Ilmiah Pendidikan Fisika AlBiRuNi, 7(2), 207-217. https://doi.org/10.24042/jipfalbiruni. v7i2.2703

Ismail. (2016). Diagnosis kesulitan belajar siswa dalam pembelajaran aktif di sekolah. Jurnal Edukasi, 2(1), 30-43.

Kheong H, \& Fong. (1982). Diagnosis and remediation in mathematics. Teaching and Learning, 2(2), 19-22.

Kumari, A., \& Bhattacharya, S. B. (2016). Item analysis of diagnostic test in english language skills of secondary 
school students. IOSR Journal of Research \& Method in Education (IOSR-JRME), 6(4), 1-5. https://doi.org/10.9790/73880604010105

Lavonen, J., Meisano, V., Byman, R., Uiito, A., \& Juiit, K. (2005). Pupils interest in physics: A survey in Finland. NorDiNa, 2(5), 72-85.

Ma'rifah, D. R. (2017). Diagnosis kesulitan belajar mahasiswa pada mata kuliah perkembangan peserta didik. Jurnal Pendidikan Biologi Indonesia, 3(1), 88-94.

Maisura. (2014). Remedial teaching matematika didasarkan pada diagnosa kesulitan siswa kelas II madrasah tsanawiyah. Jurnal Didakti Matematika, 1(1), 1-8.

Makmun., \& A. Syamsuddin. (2014). Psikologi Pendidikan. Bandung: PT. Remaja Rosdakarya.

Masyuni, S., \& Asyhari, A. (2019). Implementasi pendekatan konflik kognitif berbasis metode eksperimen terhadap penguasaan konsep dan kemampuan berpikir kritis. Indonesian Journal of Science and Mathematics Education, 2(2), 184193.

https://doi.org/10.24042/ijsme.v2i2.4 324

Maulana, P. (2012). Usaha mengurangi terjadinya miskonsepsi fisika melalui pembelajaran dengan pendekatan konflik kognitif. Jurnal Pendidikan Fisika Indonesia, 6(2), 98-103. https://doi.org/10.15294/jpfi.v6i2.11 20

Mulhayatiah, D., Setya, W., \& Suhendi, H. Y. (2019). The impact of digital learning module in improving students' problem-solving skills. Jurnal Ilmiah Pendidikan Fisika AlBiRuNi, 8(1), 11-22. https://doi.org/10.24042/jipfalbiruni. v8i1.3150

Mulia, A., Tumanggor, R., Ringo, E. S., \& Harliadi, M. D. (2020). Detecting students' misconception in simple harmonic motion concepts using four-tier diagnostic test instruments. Jurnal Ilmiah Pendidikan Fisika AlBiRuNi, 9(1), 21-31. https://doi.org/10.24042/jipfalbiruni. v9i1.4571

Munene, J. N., Peter, K. R., \& Njoka. (2017). Influence of remedial program on academic performance of pupils in public primary schools in Nyahururu District, Kenya. Journal of Research \& Method in Education, 7(5), 45-50. https://doi.org/10.9790/73880705024550

Munirah. (2018). Peranan guru dalam mengatasi kesulitan belajar siswa. Tarbawi: Jurnal Pendidikan Agama Islam, 3(2), 111-127.

Negoro, R. A., Hidayah, H., Subali, B., \& Rusilowati, A. (2018). Upaya membangun keterampilan berpikir kritis menggunakan peta konsep untuk mereduksi miskonsepsi fisika. Jurnal Pendidikan (Teori Dan Praktik), 3(1), 45-51. https://doi.org/10.26740/jp.v3n1.p45 $-51$

Perdana, R., Rosana, D., \& Soeharto, S. (2019). Specific open ended assessment: Assesing students critical thinking skill on kinetic. Jurnal Ilmiah Pendidikan Fisika Al-BiRuNi, $8(2)$, 127-140. https://doi.org/10.24042/jipfalbiruni. v0i0.3952

Putra, I., Adlim, A., \& Halim, A. (2016). Analisis miskonsepsi dan upaya remediasi pelajaran listrik dinamis dengan menggunakan media pembelajaran lectora inspire dan PhET Simulation di SMAN Unggul Tunas Bangsa. Jurnal Pendidikan Sains Indonesia , 4(2), 13-19.

Ramadhani, R., Hasanuddin, \& D, A. M. (2016). Identifikasi miskonsepsi siswa pada konsep sistem reproduksi manusia kelas XI IPA SMA Unggul. Jurnal Ilmiah Pendidikan Biologi, 
$1(1), 1-9$.

Redhana, I. W. (2019). Mengembangkan keterampilan abad ke-21 dalam pembelajaran kimia. Jurnal Inovasi Pendidikan Kimia, 13(1), 2239-2253.

Sheftyawan, W. B., Prihandono, T., \& Lesmono, A. D. (2018). Identifikasi miskonsepsi siswa menggunakan four tier diagnostic test pada materi optik geometri. Jurnal Pembelajaran Fisika, 7(2), 147-153.

Siahaan, P., Dewi, E., \& Suhendi, E. (2020). Introduction, connection, application, reflection, and extension (ICARE) learning model: The impact on students' collaboration and communication skills. Jurnal Ilmiah Pendidikan Fisika Al-BiRuNi, 9(1), 109-119.

https://doi.org/10.24042/jipfalbiruni. v9i1.5547

Silung, S. N. W., Kusairi, S., \& Siti Zulaikah. (2017). Diagnosis miskonsepsi siswa SMA di Kota Malang pada konsep suhu dan kalor menggunakan three tier test. Jurnal Pendidikan Fisika Dan Teknologi, 2(3), 95-105. https://doi.org/10.29303/jpft.v2i3.29 5

Soewarno, Nurmasyitah, \& Desi. (2016). Pelaksanaan program remedial di SD Negeri Cot Baroh Kecamatan Glumpang Tiga Kabupaten Pidie. Jurnal Ilmiah Mahasiswa FKIP Unsyiah, 1(1), 1-10.

Stevenson, C. S., Whitmont, S., Bornholt, L., Livesey, D., \& Stevenson, R. J. (2002). A cognitive remediation program for adults with attention deficit hyperactivity disorder. Australian and New Zealand Journal of Psychiatry, 36(5), 610-616.

Tarmizi, Halim, A., \& Khaldun, I. (2017). Penggunaan metode eksperimen untuk mengatasi miskonsepsi dan meningkatkan minat belajar peserta didik pada materi rangkaian listrik di SMA Negeri 1 Jaya Kabupaten Aceh Jaya. Jurnal IPA Dan Pembelajaran IPA (JIPI), I(2), 149-158.

Taufiq, M. (2012). Remediasi miskonsepsi mahasiswa calon guru fisika pada konsep gaya melalui penerapan model siklus belajar (learning cycle) 5E. Jurnal Pendidikan IPA Indonesia, 1(2), 198-203. https://doi.org/10.15294/jpii.v1i2.21 39

Wartono, W., Alfroni, Y. F., Batlolona, J. R., \& Mahapoonyanont, N. (2019). Inquiry-scaffolding learning model: Its effect on critical thinking skills and conceptual understanding. Jurnal Ilmiah Pendidikan Fisika Al-Biruni, $8(2)$, 245-255. https://doi.org/10.24042/jipfalbiruni. v8i2.4214

Yolanda, \& Yaspin. (2017). Remediasi miskonsepsi kinematika gerak lurus dengan pendekatan STAD. Science and Physics Education Journal (SPEJ), 1(1), 39-48. https://doi.org/10.31539/spej.v1i1.76

Yulika, R. (2019). Pengaruh kecerdasan emosi dan motivasi belajar terhadap prestasi belajar siswa di SMP Negeri 1 Sengkang. Jurnal Inspiratif Pendidikan, 8(2), 252-270. 